\title{
THE LAWYER IN A CHANGING WORLD
}

\author{
An Adoress By Dr. W. G. Fragomann*
}

It is a great pleasure to be here, even though I must apologize to you for the obviously hurried and improvised character of this meeting. While I was at Toronto, for nearly five years, I never had an opportunity to get out to Western Canada. When the Canadian Institute of International affairs asked me quite a long time ago to do a speaking tour of Canada, I said that I wanted to go to Western Canada, for I did not feel I could be a complete person, much less a complete ex-Canadian, without having done so.

Dean Bowker has very graciously referred to my various activities, all of which adds up to saying that I know less about more subjects than anybody else who teaches or professes law. Therefore, in this talk, I thought I might perhaps put before you certain reflexions which do not refer to any particular subject or field of law but which are concerned rather with a general approach. Particularly those of you who have had the benefits of being instructed in jurisprudence by Dean Bowker will realize the importance of a general approach.

My most abiding interest in studying and teaching law in different countries and in a rather considerable variety of subjects has always been the interaction of law and social change. I think that if all the perils and all the upheavals, which are perhaps a little less marked in this peaceful, optimistic and forward-looking country than they are as you move further East and the nearer you get to Europe, if all these perils were completely realized, men would become more aware of the problems that confront us.

We live in a very exciting period, exciting for the lawyer, the student of law, and indeed, for everyone who is in any way concerned with the law or with public life. We are moving in a changing society, and in this Province of Alberta, which has, within a decade, developed from a rather quiet, essentially agricultural province into one of the major oil centres, the change is especially noticeable. Alberta has become a dynamic and extremely important industrial centre in the space of a very few years. Here, then, especially, these matters are particularly worthy of consideration.

The task of the lawyer, not only of the lawyer, but notably so, since the legislative body in most countries naturally comprises a high proportion of lawyers because of their general training in public affairs-the task of the lawyer is an important one. This group also comprises the body of judges who apply the law and by their decisions assist in the evolution of legal principles. The law teachers also have an increasingly important task before

-Wolgang G. Friedmann. Professor of Law, Director, International Legal Research, Columbia University, Dr. iur., Berlin, 1930; LL.M., London, 1936; LL.D., 1942; LLM., Melbourne, 1948. This address was given by Dr. Friedmann to the law students of the University of Alberta on March 24, 1959. 
them. It is their function to take steps to see that legal principles are well and efficiently applied. It is for the teachers in the law schools to construe systematic discipline gleaned from a welter of cases and statutes (increasingly from statutes), and from them to arrive at certain well-defined principles. This is the task of the law schools as well as that of the ordinary practitioner, not only as a practitioner, but also as an educated citizen as a leader of his society. They are all concerned with this. You should all be concerned with it.

Law is not just an attempt at syllogistically arranging cases and deducing certain conclusions from logical premises. It is obvious that if this were so, there would not be such myriads of cases, such a flood of explanatory articles, and so many lawyers making a living in the work of attempting to reconcile various principles and decisions.

Certain things happen in the process of moulding and developing the law while applying it. This has been more obvious in past times. As late as the 18th century in England, when reports were few and not official, when case law was not organized as it is today and statute law was relatively insignificant, judges, though they tended to refuse to acknowledge it, had creative functions that they could exercise to a greater or lesser extent. The great Lord Mansfield used this relative liberty that was left to him, and developed a great body of new legal principles. His work was notable in the field of commercial law, in the area of contract, and in other fields as well. He had a remarkable way of changing the existing situation by saying that this or that reporter was not reliable, and that his report did not, therefore, correctly state the law. We cannot do that today. If you have no authoritative law you do have at least a great mass of material which has to be adapted in each case to the individual situation.

The creative task, however, is still there. It is never dormant, and it depends always to some extent on the grasp that the judge has of the law on the subject, assisted always to a great extent by the presentation to him by the lawyers of the cases which are relevant to the question for decision.

The law teachers are coming into their own in the common law world as they have in the world of civil law. It is our duty to be aware of the problems that confront us. We must mould new principles in response to the new situations that arise every day in a changing society.

You will recall the celebrated principle of Donoghue v. Stevenson, the snail-in-the-bottle case. This developed a principle that had never been enunciated before. It was really a new departure, though it masqueraded as just a technical question, as to, where there was a contract between $A$ and $B$, and a product manufactured by $A$ had done injury to $C$, whether or not $C$ had a cause of action. As you no doubt know, the House of Lords by a bare majority decided this case in the affirmative and laid down a new doctrine of responsibility of manufacturers for their products, not to the purchaser, but to the ultimate consumer.

This principle had been advanced a little earlier in the United States Courts under the leadership of the late Mr. Justice Cardozo: that is, the

1[1932] A.C. 562. 
principle that a direct action of the person injured by a product against the manufacturer would lie, even though no contractual relationship could be said to exist (Buick v. MacPherson). ${ }^{2}$ It sounds pretty technical. What it meant in fact was that in the age of mass manufacture, the law had to adjust itself to conditions as they had now become. The day of the direct relationship between manufacturer and consumer had now gone: the personal relationship had vanished. No longer was it a matter of an individual producing a product for someone who would buy it directly from him. Now products were packaged in great quantities, packaged and sealed, and sent off to distant points where they would be distributed through a retailer. Through the retailer was established a link. The law must respond to it. It is appropriate that the person, usually the corporate person, who runs the manufacturing enterprise and determines the quality and mode of manufacture, should be held liable to the consumer for any injury that he should suffer by reason of a defective process or by reason of the manufacturer's fault. It is something which, in a sense, is linked up with the principle developed earlier, of vicarious liability of the master for the torts of his servant. It is, in fact, a question of deciding where the loss should lie, and of shifting the burden to the person most able to bear it. Given the distribution of resources, the manufacturer is more capable than anyone else of sustaining the burden. In this context the whole concept of negligence has been moulded and transformed in the case of manufacturer's liability for defective products. This concept has even been extended to liability for automobile accidents caused by defective manufacture or defective repair.

The concept of negligence has now moved a long way from the former concept of an individual fault. Fault, in the case of a manufacturer's liability, has now moved very close to strict liability. Famous cases have dealt with numerous defective products. We have mentioned the bottle of ginger beer. In another case, an Australian case, a suit of winter underwear which had been put out for sale contained such a large quantity of sulphur in its fabric that the person who ultimately bought it became afflicted with a form of dermatitis. When harm is done to the ultimate consumer there is now a presumption which is very difficult to rebut, that the fault lies with the manufacturer. He is generally held liable not only for the negligence of his many employees, but also for the negligence of independent contractors whom he may employ as well.

Negligence is a nomenclature that has considerably altered its meaning from early times. In the case of motor car accidents, as I have said, there has been a similar development towards strict liability. In this field another important development which has not yet been sufficiently explored by teachers and students of law and by researchers, is the fact that, more and more, by compulsion of law or as a matter of overholding practice, the actual burden has come to rest upon the insurer. There is a gradual spread of compulsory third party liability. The United States insurance companies have resisted this as the first step to state control and there has been a great deal of

2217 N.Y. 382. 
opposition to compulory insurance or government-sponsored insurance schemes. A report was prepared upon this subject at Columbia University. The Supreme Court of New York has introduced this principle. At the time I left, it was still being resisted, but it is overwhelmingly known in countries outside this continent and I believe it is bound to spread.

The fact that the burden has shifted may not be admitted universally as a principle of law, but it has in fact shifted in practice. Juries still operate as before, but on this continent, in most questions of civil liability, the times have produced an altogether different emphasis. The actual burden is not on the nominal defendant. It now lies upon the insurers of the defendant or against those of a third party who insures against such liabliity at a regular and fixed premium.

In Saskatchewan, although common law actions are still brought, they have altogether departed from the principles of fault liabliity. Now there is in that province a principle of minimum insurance for the loss that occurs.

These developments have effectively been brought about. Many judges say that these are matters for the legislature to deal with. They absolutely deny that changes of such a momentous nature can be brought about gradually, imperceptibly, and as a matter of altered emphasis. On that principle, the common law of contract and tort would now be something like it was in 1300 , because there has been no visible break. If today you took out a textbook on torts which was used in 1910, it would be of very little use to you; the principles would no longer be valid. It would be completely unusable. Almost no authority would be valid today. The overwhelming bulk of authority in the field of Tort dates from this century and a great deal more has grown up within the past thirty years. This great change indicates that in that field, at least, the judges have changed the law in many important respects. They have changed the law to conform with the changing social science and the greatly altered economic situation.

Our society has rapidly been transformed from an agricultural and pastoral society, built on a framework of villages, into one that at least in the major countries in the West has come to be highly industrialized, greatly urbanized, commercialized, and one which has had to take into consideration a host of new problems which have come with the change. Now we have to deal with problems like injury to property from proximity to factories, accidents to persons, and the like. Our way of life has changed out of all recognition. As I said, in major cases, the work of the legislature must take care of these changes. The legislature, however, is not very often much preoccupied with what we may call "lawyers' law". In many cases, the legislature must spend much more time and energy on problems of "political" importance. Such things must be dealt with as subsidies to be paid to farmers, social security plans, old age pensions, veterans' benefits, loans for the building of homes and 'that kind of thing' not to speak of major issues like questions of foreign economic aid such as occupies the United States Legislature a good deal of the time.

It would be disastrous if, given the little time that is left for lawyers' law 
legislation, the lawyers themselves, and in particular, the courts, should be passive and satisfied to wait for something decisive to happen on the side of the legislature. This often does not happen for generations.

The true picture today is one of constant give and take, of an interrelation in which lawyers must think out and prepare the legal principles with which they work. At some time, when it becomes a matter of major importance, the legislature will take over and systematize it. But in the meantime, individual judgments are deeply significant in the development of the law. Changes by precedent are less clearly spelled out than changes which are created by the legislature but they are often more significant.

Interpenetration of public and private law in our time is a most interesting and exciting concept. Traditionally the branches of law have developed under the guidance of the bar in England, and in conditions that were existing in the 15th, 16th and 17th centuries, around certain subjects. The law of property or the law of conveyancing, was an important matter, at least for the propertied classes in whom the lawyers were largely concerned. By historical accident of English development the separation between law and equity, in a sense a very arbitrary and unreal division, was created and has been perpetuated down to our own day. The equity court and the whole sphere of equity law was developed because the common law courts were too rigid in their application of precedent and often worked hardships in individual cases. Development of the forms of action came in response to the political conflict between the king and parliament and the courts. For centuries, as you know, the common law and equity developed along separate lines. This was not a reasonable development, for it involved tearing apart fields that were really one. It is quite absurd to deal with contract, including breach of contract and the remedies for it, as common law, and then to have specific performance, injunction and rectification belonging exclusively to Equity. Nobody today can adequately study the law of contract without knowing both the principles of common law and the equity principles that deal with the subject. Generally, now, since 1875 , the common law and equity jurisdictions have merged, though this has not yet happened in a number of states in the United States. New South Wales still separates the two, despite the mergers that have occurred elsewhere. In England counsel practise in common law or in equity. This is totally out of date. In Columbia we have abolished equity as a separate subject. This is a good thing, in my opinion. Equity as a separate subject is just a relic of the past and I think that it has no place as a distinct study. There are many difficulties in the study of Equity, although that is not the reason why I believe that it should be discontinued. I really do think that we must, by and by, overcome there historic differences.

I come now to something more significant. We live today in a society in which everywhere, even in such an anti-socialist-minded country as the United States, the state and the government are exercising functions that would have been quite unimaginable a century ago. It is a matter of political philosophy. In the United States, we pride ourselves upon the fact that we are not socialists, that we are the last bulwark of free enterprise. This amounts 
to political mythology. You will hear people say in the United States that the government should be concerned only with those things that properly fall within its sphere, such as the provision of armed forces for defence, foreign affairs, and the levy of some adequate form of taxation for the purpose of paying for these services. In fact, if the government were to restrict its activities to such basic matters as these, there would today be revolution in the United States. The government is now concerned with a multitude of regulatory and supervisory functions of all kinds, from social insurance to the conduct of all manner of public operations such as the T.C.A. in Canada, the C.N.R., and other matters directly conducted by public enterprise.

Generally, the state today is expected to take the responsibility for the development of the body politic. This responsibility differs in extent and in - degree from one country to another, from one extreme, of which the U.S.S.R. is an example, to the other, of which examples are the United States or this province of Alberta. But these are, if you were to look back at them in perspective, purely differences of degree. Public law, which itself is a recent development, the whole pattern of administrative law, is getting increasingly mixed up with private law. Our teaching inevitably proceeds largely on the differences, instead of on the basis of the similarities and on the many fields where the two fields are indistinguishable. People who consider themselves public law men are concerned with matters of administrative law, while people who consider themselves as primarily private law men are concerned with the older concepts of law such as constract, tort, property and so on. If you want, however, to be a good lawyer, indeed, if you want to be an adequate citizen, you can't be just one or just the other. There is hardly a subject today in which there is not an intermingling between the two fields. Public law is beginning to have such an impact on private law that it is impossible to consider any branch of legal study independently of this new development. In contracts, for instance, the old contract law as you learn it in the text-book is concerned with an individual or individuals making their own rules with regard to their agreements. This is fiction today. Contracts as to transport, insurance, rents, mortgages are all standard contracts in which the individual will simply sign on the dotted line, for the most part voluntarily. It is not a matter of equal bargaining any more. The law has put certain correctives into most commercial contracts. The terms on a ticket must be clearly set out. Hire-purchase and financing transactions must be clearly apparent. By and large, however, this is a kind of corporate act in which the individual accepts the conditions that have been worked out for him either by the appropriate association of insurers, or airlines, or shipping lines. If he doesn't like it he can leave it, but he cannot change it. Certainly the average man cannot. The conditions are simply laid down there for him to accept or reject. Because that is so, there is more and more need for public law.

There are States which make certain conditions invalid if they are found to be excessively oppressive. Some contracts are simply illegal. There are a great many regulations covering the exercise of monopoly power. Contracts of service are standardized today, and their terms are subject to 
legislation of an essentially public nature. Many conditions of illegality now exist that were unheard of before. Restraint of trade is illegal in the United States as well as in Canada. A whole new branch of law has developed regarding restrictive trades. There are anti-trust laws. There has therefore been a tremendous influx of public law into what formerly was purely "private law." The Mogul case, in $1889^{3}$ was settled purely as a matter between private parties when one was squeezed to the ground by the more powerful party that was in a position to dictate conditions. In 1889 this was still regarded as a matter for the courts to adjudge, but it is entirely different today.

Consider this whole field of administrative law which has become established as an elaborate discipline on the continent. Starting from France after the time of Napoleon, the concept of public law and administrative law spread and led to a whole separate science of public and administrative law and a whole hierarchy of administrative tribunals. We need to elaborate the relations between public authority and the individual. It is not often realized how complex and how important these are. Public law is mixed up with the law of contract and tort; they are so intermingled that the two fields are inextricably blended in our day. Take, for example, the whole field of contracts between governmental authorities and public corporations and individuals. I speak in particular of such public corporations as the T.C.A., the C.N.R., as well as a number of the public authorities which have been created in Canada since the last war. These now deal extensively with individuals. There is, of course, an attempe to adapt these transactions in which you have, on the one hand a government authority and, on the other hand, an individual, to the established principles of the common law of contract. On the continent there have been elaborated a mass of principles for dealing with such contracts as these. We have blended standard conditions with the common law principles. Now the government departments, for instance, lay down something very like a standardized contract setting out the terms by which it purchases supplies and services, for instance, from individuals or private contractors. Special elements arise in cases like this because the public authority must sometime be bound by considerations other than those of the law of contract. Emergency conditions can arise: a war, for instance. The private interests also have to be taken into account so that they may not be left with all the expense and none of the profit. If a satisfactory compromise is not worked out, it would be difficult for a private company or for an independent contractor to deal with the government authority at all. We do not, of course, allow full damages for lost property in a national emergency, but there must be compensation for legitimate expenses.

There is a whole field of law here; it is a field of vast importance which is in fact a mixture of public and of private law principles. Let us take, for instance, the question of the liability of the government in cases of Tort, such as accidents: this alone could be the subject of several lectures. We have gradually had a strengthening of the principle that the government must be liable to the individual in Tort, and have abandoned the antidiluvian principle

\footnotetext{
8(1889) 23 Q.B. 598.
} 
that "the King can do no wrong". This fiction cannot live on today in a modern world. The King was absolute and in fact this was a feudalistic principle of government. It is not quite as simple as it sounds, however. You simply cannot lay down the rule that the government must be liable in all circumstances. There are certain conditions in which government authorities must be permitted to have a certain amount of discretion. American decisions have wrestled with this problem. There was a famous Texas explosion arising from carelessness in connection with a cargo shipped after the war by way of economic aid. The cargo was highly explosive. Was the government liable? The Supreme Court said no, the Government in the exercise of a discretionary activity could not be held liable. Aid was given at discretion. Subsequent decisions have laid stress on the point that it is true that there must be an element of discretion. As to aid, there is that element, but the principle of due care must still be applied. The whole matter is extremely complex. Here again, you get a mixture of public and private law.

In the matter of property it would be absurd to suppose that a lawyer today could presume to deal with property law unless he had a thorough knowledge of town planning and zoning legislation. There are many compulsory conditions under which property law operates today which restrict the terms under which property may pass or be developed and which in fact invalidate certain transactions or create compulsory changes.

Lastly and briefly, we must deal for a few moments with the field of international law. International law is, of course, a matter of increasing importance to states which, like the United States and Canada, pass rapidly from the isolation of the 19th and early 20th century to far-reaching international responsibilities. Of course, international law traditionally has been chiefly concerned with such matters as the conditions under which one state will recognize a foreign state or government, or with the limits of territorial waters, or with the principles and conditions under which a state may be responsible for injury done to aliens, and things of this sort. Diplomatic immunities, and a number of other related matters are very important, and they are always in flux. For centuries it has been more or less accepted that the territory of a state extends for three miles into the sea around its shores. Now this concept is also in flux, largely because of the claims of new sovereign states, such as Indonesia, Chile, and Peru, which want to protect themselves by a larger band of territorial waters, and also because of the incidence and exploration of mineral resources such as oil from the sea soil. In the space of little more than ten years, this question has developed into an elaborate doctrine of the continental shelf and now many countries are seeking to overcome by a variety of means the old concept of the traditional freedom of the seas.

Another development, almost entirely new, which shows the interpenetration of public and private law, one in which Canada will increasingly be concerned, that of agreements between industrial groups and the government, not to speak of the governments of other powers. There are also, in this field, special contracts for exploration and development of certain resources: minerals, 
manufacturing facilities, and so forth. There are a great many problems connected with underdeveloped countries. These countries need assistance. They are, however, very proud and independent. They will need capital, machinery, and the skilled scientific resources which the more advanced nations can give them. This assistance must be given in such a manner as to enable these people to cope with each other without creating political problems. Boundary lines must be drawn, and these create causes of difference. By and large this is one basic phenomenon of our times which we cannot afford to ignore. The law must take all these problems into account. There will be a great need for the rendering of technical assistance to underdeveloped countries by those others which are more advanced. In most cases, this leads to agreements which must be drawn up between sovereign states. Saudi Arabia, India and the United Arab Republic are among those nations whom we must consider in this connection.

A private firm cannot cope with the problems which arise in the course of dealing with foreign countries. Public law lays down the conditions under which certain grants, for instance, will be given. This is chiefly public law, but it has a great many aspects which look like private law. On one hand, you have a sovereign state, and on the other a private party. They cannot, of courses, deal upon the same level. It is important, indeed essential, to develop legal principles that will facilitate the dealings that must take place on this plane. It is necessary to take into account that a sovereign state must have the freedom to regulate the basic principles under which it enters into agreements. A sovereign state has duties to its people as well as to those with whom it enters into contractual agreement. On the other hand, some semblance of fidelity to the principles of contract must be maintained, otherwise no firm would be willing to invest at all in foreign ventures. Some of the technicians in the advanced countries have years of experience, which can be extremely valuable, even essential, to those countries where technical skill and knowledge are at a premium. Certain principles of legal security have to be developed. By a blend of principles taken from public international law and private international commercial law, a system must be worked out by which commerce can be efficiently carried on within the framework of the new world. It is an exciting prospect. There are numberless new activities in which lawyers will now engage. Out of the work of lawyers and public men, given peace in which to develop, certain new principles will emerge that will constitute a blend of public and private law.

This has been a very brief and random journey through a large variety of subjects, and, as I said at the beginning, it is not because as a teacher of jurisprudence one tends to roam over a vast number of subjects. It is all one picture, really.

My intention has been to bring home to you the many exciting tasks that are before a lawyer in this new day. There are numberless problems, and it may fall to you to find the solution to some of them as the development of the legal system progresses to keep pace with a changing world. 